\title{
Community structure and spatial patterns of soft-bottom macrozoobenthos in Oualidia lagoon, Moroccan Atlantic
}

\author{
EL ASRI Fatima*1,5, ERRHIF Ahmed ${ }^{1}$, MARTIN Daniel ${ }^{2}$, TAMSOURI Mohamed-Naoufal ${ }^{3}$, \\ MAANAN Mohamed ${ }^{4}$ and ZIDANE Hakima ${ }^{5}$
}

\author{
${ }^{1}$ Health and Environment Laboratory, Faculty of Sciences Ain Chock, University Hassan II, B.P. 5366 Maârif, \\ 20100 Casablanca, Morocco \\ ${ }^{2}$ Centre for Advanced Studies of Blanes (CEAB-CSIC), Accés a la Cala St. Francesc, 14 Blanes 17300, Girona, \\ Spain \\ ${ }^{3}$ Fishing Laboratory, National Institute for Fisheries Research (INRH). - Tanger, Morocco \\ ${ }^{4}$ UMR 6554 LETG-Nantes, University of Nantes, BP 81227, 44312 Nantes, France \\ ${ }^{5}$ Prospection of Littoral Resources Laboratory, National Institute for Fisheries Research (INRH). Road Sidi \\ Abderrahmane Club Equestre Ould Jmel - Casablanca, Morocco \\ * Corresponding author (e-mail: fatimaelasri25@gmail.com)
}

\begin{abstract}
The paper analyse the composition, structure and spatial organization of the soft-bottom macrozoobenthos inhabiting Oualidia lagoon (Moroccan Atlantic coasts), as well as their relationships with the main environmental variables. Material for the study was collected from 43 stations in winter 2013. A total of 56 species belonging to 6 phyla were recorded and identified. Species diversity was highest in molluscs, crustaceans and polychaetes. We used a Hierarchical Ascending Classification and a non-Metric Multidimensional Scaling to characterize the macrozoobenthos of the lagoon. We identified three groups of stations arranged from the outer -most to innermost areas of the lagoon, harbouring a Cerastoderma edule, a Tritia pfeifferi and a Tanais dulongii assemblage, respectively. The trophic structure of the macrozoobenthos was dominated in density by deposit-feeders $(88.1 \%)$ and species richness by carnivores $(20 \%)$ and detritivorous $(20 \%)$. The BIO-ENV analysis showed that the combination of granulometry, salinity and temperature were the major factors controlling the spatial distribution of the macrozoobenthos in the Oualidia Lagoon.
\end{abstract}

Keywords: Macroinvertebrates, Biodiversity, Environmental factors, spatial patterns, Oualidia lagoon, Morocco.

\section{Introduction}

In marine ecosystems, soft-bottom macrofauna represents a main basal component of the food web. Most macrobenthic species represent an important nutritional resource for many higherlevel consumer, such as epibenthic crustaceans, fish and especially shorebirds (Jędruc et al, 2019). Shorebirds in particular are typically benthivorous and the most important consumers of intertidal benthic communities (Herman et al. 1999; Goss-Custard et al. 2006, Platell et al. 2006).

Benthic communities are also widely used to monitor the effects of environmental change. Being relatively long-living, compared to meio- and micro-benthos, they integrate water and 
sediment quality conditions with time and thereby, indicate temporary and chronic disturbances (Gray et al. 1990; Borja et al. 2000; Blanchet et al., 2008). The composition and structure of macrobenthic fauna are strongly correlated with the ecological conditions prevailing in the water-sediment interface, where multiple effects of organic enrichment and pollution occur (Borja et al. 2000; Dauvin et al. 2016). Thus, having a detailed knowledge of the macrobenthos appears essential to understand the functioning of coastal ecosystems including lagoons, and is a mandatory step to implement effective management and conservation measures.

Costal lagoons occupy around a 13\% of the world coastline (Kjerfve 1994), playing a key ecological role (Velasco et al. 2017). They are among the marine habitats with the highest biological productivity (Kennish \& Paerl, 2010), while being subjected to intense anthropogenic activities as they provide many goods and services. Among them, there are valuable social and economic activities such as traditional fisheries of fish and molluscs. Oualidia lagoon is not an exception and their natural resources supports many aspects of local people lives, including economic, cultural, and community relationships (Maanan et al. 2014). In addition, its biological, ecological and landscape potential favoured the a growing development of recreational and tourist activities. Altogether, these various human activities contribute to generate pressures that may impact biodiversity and cause ecosystem malfunctioning (Dauer et al. 2000; Borja and Dauer, 2008).

Moroccan coasts include a rich network of lagoons, one of them being Oualidia, which is located in its Atlantic coast. This lagoon provides a valuable environment for a rich variety of plants, birds, fish, and other wildlife (El Hamoumi et al. 2003). It is currently considered a Natural Park and, being the most important wintering area for migratory birds in Morocco (El Hamoumi et al. 2003), it is also considered a Wetland of International Importance (under the RAMSAR Convention).

Despite its intrinsic interest, the studies on Oualidia lagoon mainly focused on oceanography (Bennouna et al. 2000; Hilmi et al. 2005; Damsiri et al. 2014; Maanan et al. 2015) and wholesomeness (Bellucci et al. 2002; Zourarah et al. 2007; Hassou et al. 2014). Only three approached the analysis of the biodiversity of benthic species (Chbicheb 1996; El Asri et al. $2015,2017)$. The aim of the present paper is, thus, to provide an overview of the biodiversity of the whole soft bottom macroinvertebrate assemblages inhabiting Oualidia lagoon, with particular emphasis on their distribution patterns and community structure, as well as their relationships with the main environmental variables explaining their spatial distribution.

\section{Materials and methods}

\section{Study area}

Oualidia lagoon, located on the Atlantic coast of Morocco between El Jadida and Safi $\left(32^{\circ} 44^{\prime} 42^{\prime \prime} \mathrm{N}-09^{\circ} 02^{\prime} 50^{\prime \prime} \mathrm{W}\right)$ (Figure 1), has a surface area of $3.5 \mathrm{~km}^{2}$ and exchanges water with the ocean through a $150 \mathrm{~m}$ wide major inlet. During spring, the tidal regime gives rise to a secondary shallower inlet about $50 \mathrm{~m}$ wide. The lagoon is characterized by having lateral channels connected to a meandering main channel with an average depth of $2 \mathrm{~m}$ and a maximum depth during flood tides not exceeding $5 \mathrm{~m}$ (Carruesco 1989). Flood tides cover more than $75 \%$ $\left(2.25 \mathrm{~km}^{2}\right)$ of the lagoon surface, bringing salt water up to the upstream reaches of the lagoon and into a saline marsh. 


\section{Sampling and processing}

The soft bottom macrofauna was sampled at 43 stations (Figure 1) during winter 2013. Sediment samples were collected using a Van Veen grab, with two replicate samples in each station $\left(0.125 \mathrm{~m}^{2}\right.$ in surface area). Samples were washed in situ through a $1 \mathrm{~mm}$ mesh sieve and fixed in a $10 \%$ seawater formaldehyde mixture.

Superficial water salinity and temperature were recorded at each station by a thermosalinometer. One additional sediment sample was also collected at each station to measure chlorophyll a concentration, grain size, and organic matter content. The chlorophyll 'a' content was determined according to the Lorenzen method (Holm-Hansen et al. 1965). Grain size was measured with a laser granulometer (Malvern, Mastersizer) at the LETG (Littoral, Environnement, Geomatique, Teledetection) (UMR 6554, University of Nantes). The percentage of organic matter was obtained as the weight losses after ignition at $450^{\circ} \mathrm{C}$ for 4 hours.

\section{Data analysis}

Macrobenthic communities were described through the following indicators: species richness, abundance, Shannon diversity (H', as log2) (Shannon 1948) and evenness (J') (Pielou 1966), calculated using the PAST software (Paleontological Statistics v2.14) (Hammer et al. 2001). Hierarchical Ascending Classification (HAC) based on Bray-Curtis distance (Ward's method) and non-metric multidimensional scaling (nMDS) were used to analyse the structure of the sampling stations based on the density matrix, using the SYSTAT 11 program. Densities were transformed $\log 10(\mathrm{x}+1)$ to limit the influence of the most dominant taxa, and the species with a single occurrence in the lagoon were omitted from the analysis. The IndVal index (Dufrêne and Legendre 1997) was calculated for each species in each assemblage and the species showing the highest value were used to describe the respective assemblages. A multivariate correlation (BIOENV) (Clarke \& Ainsworth 1993) was used to test the observed patterns and to define the existing correlations between species abundance and abiotic parameters, which allowed us to quantitatively explore the relationship between the levels of different factors and the biotic patterns. The BIOENV analysis was based on the Euclidean distance for the abiotic dataset and on the Spearman rank correlation, and were carried out in the R computational software 3.4.3. The analysis of the functional structure of the assemblages was based on the trophic groups assigned to the different macrobenthic taxa identified, according to Fauchald \& Jumars (1979) and notably modified by Grall and Glémarec (1997), Hily and Bouteille (1999), Afli and Glémarec (2000), Pranovi et al. (2000) and Afli et al. (2008).

\section{Results}

\section{Environmental data}

Most environmental descriptors of Oualidia lagoon showed a clear gradient from outer to inner parts of the lagoon: temperature increased from 16.9 to $19.9{ }^{\circ} \mathrm{C}$ (Figure 2), salinity decreased from 10.1 to $39.5 \%$ (Figure 2), , organic matter increased from 1.94 to $31.97 \%$, showing the maximum at station 20 and the minimum at station 39 near the sandpit where the hydrodynamic regime favours sediment instability (Figure 3) And the granulometry was mainly sandy in the 
outer area and varied from sandy-silt to silty-sand in the inner one (Figure 3). Chlorophyll a showed a heterogeneous distribution and ranged between 1.19 and $23.41 \mathrm{mg} / \mathrm{m}^{2}$ (Figure 3).

\section{Species composition and diversity}

A total of 56 taxa were recorded, specifically 28 mollusks, 17 crustaceans, seven polychaetes, two echinoderms, one cnidarian and one insect larvae (Table 1). Molluscs were the most abundant taxa (95.3\%), followed by polychaetes $(2.7 \%)$, and crustaceans $(1.2 \%)$.

The middle part of the lagoon showed the highest number of species. Up to 21 species were recorded at stations 35 and 36 and only 1 at stations 33 and 42 (Figure 4). The highestdensity was also found in the middle part of the lagoon. Up to 5,142 ind. $\cdot \mathrm{m}^{2}$ were recorded at station 23 , while only 8 ind. $\cdot \mathrm{m}^{-2}$ occurred a station 32 (Figure 4 ). The diversity varied from 0 to 3.8 bits (Figure 5) and did not show any defined gradient, ranging in most stations between 1 and 2 bits. The evenness varied from 0 to 0.9 (Figure 5), being of less that 0.4 in several stations.

\section{Trophic structure}

The soft bottom microbenthic fauna of Oualidia lagoon can be grouped in eight feeding groups: carnivores, detritivorous, herbivorous, micrograzers, surface deposit feeders, subsurface deposit feeders, suspension feeders and scavengers,. In terms of the species richness carnivores $(19 \%)$, detritivorous $(19 \%)$, herbivorous $(18 \%)$, suspension feeders $(16 \%)$ and surface deposit feeders $(14 \%)$ were dominant, while micrograzers, scavengers and subsurface deposit feeders exhibited the lowest values (Figure 6A). In terms of density, the deposit-feeders were dominant $(88.1 \%)$, followed by the scavengers $(5 \%)$ and by a weak representation of all other groups (Figure 6B).

\section{Assemblage structure}

Three main groups of stations were identified in Oualidia (HAC, distance $=20 \%$, Figure 7A; stress level $=0.14$, nMDS, Figure 7B) showing significant differences (PERMANOVA, Table 2).

The first group included the stations from the outer part of the lagoon. It was characterized by having sandy bottoms with low organic matter, high species richness (37 species), the lowest mean density $\left(99.7 \pm 104.5\right.$ ind. $\left.\cdot \mathrm{m}^{-2}\right)$, and the highest mean $\mathrm{H}^{\prime}$ and $\mathrm{J}^{\prime}(2.5 \pm 0.8$ bit/ind. and $0.8 \pm 0.1$, respectively). The most dominant species were the crustacean Tanais dulongii, the gastropods Peringia ulvae, Tritia pfeifferi and Tritia reticulate, and the bivalve Abra alba.

The second group included the stations from the middle part of the lagoon. It was characterised by showing the highest mean density $\left(1726.8 \pm 1485.7\right.$ ind. $\left.\mathrm{m}^{-2}\right)$, a moderate species richness (31) and the lowest mean $\mathrm{H}^{\prime}$ and $\mathrm{J}^{\prime}(1.1 \pm 0.5$ bit/ind. and $0.3 \pm 0.2$, respectively). The most dominant species were the gastropods Tritia pfeifferi, Peringia ulvae and the bivalve Abra alba.

The third group included stations from the inner part of the lagoon. It was characterized by a low species richness (17 species), a density intermediate between the two previous groups $\left(209.9 \pm 188.3\right.$ ind $\left.\mathrm{m}^{2}\right)$ and moderate $\mathrm{H}^{\prime}$ and $\mathrm{J}^{\prime}(1.1 \pm 0.7$ bit/ind. and $0.4 \pm 0.2$, respectively). The sediments were characterized by a fine-grained texture and high organic matter, while the temperature was the highest.. The dominant species were the bivalve Cerastoderma edule, the 
gastropods Peringia ulvae, Haminoea cf. japonica and the polychaetes Hediste diversicolor, Capitella sp.

\section{Relationships between biotic and environmental patterns}

The highest rank correlation $($ Bio-Env, rho $=0.541)$ in Oualidia lagoon showed granulometry, salinity and temperature forming the "best combination" of abiotic parameters playing a relevant role in structuring the macrobenthic assemblages (Table 4).

\section{Discussion}

The present study aimed to analyse the spatial variability of the soft bottom macrozoobenthic assemblages in Oualidia lagoon, assessing the relationships between their spatial distribution patterns and the environmental factors driving them. Taking into account that Oualidia lagoon is affected by numerous impacts from different anthropogenic sources of disturbance, and that there is an evident lack of previous studies analyzing its macrozoobentic assemblages as a whole, our study certainly provides a good baseline and will be a useful reference for future ecological research and monitoring of environmental impacts in this lagoon, as well as in similar coastal ecosystems.

Our results proves the existence of a very pronounced decreasing gradient of salinity from the outer to the inner parts of the lagoon, where there were massive inland freshwater inflows (Hilmi et al. 2005), which agrees with our finding of marked lower salinities in the inner part. However, inland freshwater also affected the outer station 43, as previously reported (Hennani et al. 2012; Hassou et al. 2014; El Asri et al. 2015, 2017). The lower temperature at the entrance of the lagoon reflects the influence of the cold ocean waters. Being far from this influence, the mid and inner stations tended to be easily warmed due to their shallower depth and the loss of momentum (Rharbi et al. 2001; Hilmi et al. 2005; Hennani et al. 2012; Damsiri et al. 2014). The overall distribution of both granulometry and organic matter follows the dominat hydrodynamic characteristics of the lagoon, with the relatively calm inner area tending to have more fine sediments and organic matter (Maanan 2013; Zourarah 2002; El Asri et al. 2015; 2017).

The soft bottom macrofauna of Oualidia lagoon was mainly characterized by the presence of mollusks (especially gastropods and bivalves), followed by crustaceans (especially amphipods and isopods) and polychaetes (especially errant taxa). Despite the occasional presence of tunicates and cnidarians, the resulting taxonomic composition was typical of lagoon environments (Bazaïri et al. 2003; Mistri 2002). Our report of 56 taxa more than doubled the number of species (24) previously reported in the lagoon (Chbicheb 1996). We suggest that this increase can be explained by the progressively increasing organic matter contents in the sediments of the lagoon, as well as by the changes in its hydrodynamic characteristics caused by the construction of a pit upstream, but we cannot discard the fact that we have sampled four times more stations (43 vs. 10 in 1996). Compared to other lagoons (Mergaoui et al. 2003; Marchini et al. 2004; Chaouti and Bayed 2005; Touhami et al. 2019), Oualidia appears to be richer in terms of species, probably because the combined influence of a wide connection with the ocean with the progressive arrival of inland freshwaters. Accordingly, the partuclar environmental characteristics seemed to provide favorable habitats allowing the combined presence of marine, brackish and freshwater benthic organisms. 
The presence of as much as eight trophic functional groups in the macrozoobenthos is an indicator of the availability of a wide panoply of trophic resources in the lagoon (Touhami et al.2017). However, the observed trophic structure is certainly comparable with that commonly observed worldwide in other coastal lagoons, as well as in estuaries (McLusky and Elliott 2004), particularly in what concerts to the dominance of deposit-feeders in density (Bachelet et al. 2000; Gaudêncio and Cabral 2007; Marchini et al. 2000; Ysebaert et al. 2003).

The particular combination of geological, hydrographical and environmental characteristics of Oaulidia lagoon generates a macrofaunal structure characterized by three assemblages that can be clearly distinguished in the HAC and nMDS plots (Figure 7A-B) and proved to be organized along a inner-to-outer lagoon gradient (Figure 8), in a similar was as previously reported for other lagoons (e.g. Bazaïri et al. 2003; Lefrere et al. 2015): 1) the inner-lagoon, which was characterised by having highest fine sediment contents and harboured a Cerastoderma edule assemblage; 2) the mid-lagoon, which had medium grain-sized sediments and harboured a Tritia pfeifferi assemblage; and 3) the outer-lagoon, which was closer to the lagoon inlets, showed sandy sediments, and harboured a Tanais dulongii assemblage.

The spatial organisation of the lagoon and its associated benthic assemblages, as defined based on our data, agrees with the previous consideration of the lagoon as 'an estuary without a river' based on a physical oceanography approach (Hilmi et al. 2005). This also corresponded with the spatial arrangement typically characterising paralic environments, whose main descriptors responded to a gradient of confinement (Guelorget and Perthuisot 1983). Despite the absence of a river, the taxonomic organization of the macrozoobenthic assemblages of Oualidia lagoon closely resembled that of an estuarine system, where the tidal regime plays a key structuring role (Cherkaoui et al. 2003). In Oualidia lagoon, however, the main driving factor appear to be the combined influence of granulometry, temperature and salinity, which seems also to be a common trend in lagoon systems (Uwadiae 2013). However, the environmental factors controlling the species distribution may change from one paralic environment to another being, for example, vegetation and grain size in the Smir lagoon (Mediterranean coast of Morocco) (Chaouti and Bayed 2008), dissolved oxygen, temperature and salinity in the Sacca di Goro (Adriatic coast of Italy) (Mistri et al. 2001), or temperature and depth in Monolimni lagoon (Mediterranean lagoon, Northern Aegean) (Kevrekidis 2004).

\section{Conclusions}

The present study proves the high diversity and abundance of the benthic macrofauna of Oualidia lagoon, and determines the main factor(s) controlling the species distribution to be a combined influence of granulometry, temperature and salinity. We also prove that the lagoon provides a high diversity of trophic resources to the macrozoobenthic organisms, as shown by the high number (up to eight) of trophic-functional groups identified. The assemblages of the lagoon were characteristically dominated by a few species, which appears to be a common trend in lagoon macrozoobenthos and reflects its very high vulnerability and fragility. Our study helps to compensate the lack of fundamental knowledge on the structure of the benthic macroinvertebrate assemblages of the lagoon, while providing a useful tool for further ecological assessment and environmental impact monitoring of these coastal ecosystems of Moroccan Atlantic. The Additional studies of the relationships between macrobenthic communities and abiotic parameters are needed to discuss spatial and seasonal variations. 


\section{Acknowledgments}

This paper is part of a research program on coastal resources of the LPRL/DRH-Casablanca (National Fisheries Research Institute) and a contribution of DM to the research project PopCOmics (CTM2017-88080), funded by the Agencia Estatal de Investigación and the European Funds for Regional Development and to the Consolidated Research Group on Marine Benthic Ecology of the Generalitat de Catalunya (2014SGR120). We are deeply grateful to all INRH-Oualidia staff for their human quality and help during sampling, especially to Mrs Brahim Moutaki and Mrs Ahmed Kaddioui who actively participates in the field surveys. We are grateful to anonymous editors for their corrections on the manuscript. We also thank the anonymous reviewers for their valuable comments.

\section{Data availability}

Data sharing not applicable to this article as no datasets were generated or analysed during the current study.

\section{Conflict of interest}

The authors declare that they have no conflict of interest.

\section{Ethical approval}

This article does not contain any studies with animals performed by any of the authors.

\section{Sampling and field studies}

All necessary permits for sampling and observational field studies have been obtained by the authors from the competent authorities and are mentioned in the acknowledgements, if applicable.

\section{Funding}

None.

\section{Consent for publication}

Not applicable.

\section{Competing interests}

The authors declare that they have no competing interests.

\section{References}

Afli A, Ayari R, Brahim M (2008) Trophic organization of the macro-zoobenthic assemblages within coastal areas subjected to anthropogenic activities. J Mar Biol Assoc UK 88(4): 663-674. https://doi.org/10.1017/S0025315408001318

Afli A, Glémarec M (2000) Fluctuation à long terme des peuplementsmacrobenthiques de la partie orientale du golfe du Morhiban (Bretagne, France). Cah Biol Mar 41 : 67-89. 
Amanieu M, Guelorget J, Ferraris O (1980) Organisation et évolution des peuplements des lagunes littorales. Application à la macrofaune benthique des étangs palavasiens. In Recherche d'écologie théorique. In Recherche d'écologie théorique. Les strategies adaptatives. Maloine éd., Paris, 298pp.

Bachelet G, De Montaudouin X, Auby I, Labourg P. J (2000) Seasonal changes in macrophyte and macrozoobenthos assemblages in three coastal lagoons under varying degrees of eutrophication. ICES J Mar Sci 57(5): 1495-1506. https://doi.org/10.1006/jmsc.2000.0902

Banaoui A, Chiffoleau J-F, Moukrim A, Burgeot T, Kaaya A, Auger D, Emmanuelle R (2003) Trace metal distribution in the mussel Perna perna along the Moroccan coast. Mar Pollut Bull 48: 378-402. https://doi.org/10.1016/j.marpolbul.2003.11.007

Bazaïri H, Bayed A, Glémarec M, Hily C (2003) Spatial organisation of macrozoobenthic communities in response to environmental factors in a coastal lagoon of the NW African coast (Merja Zerga, Morocco). Acta Oceanol Sin 26: 457-471. https://doi.org/10.1016/S0399-1784 (03)00041-0

Bellucci L.G, Frignani M, Paolucci D, Ravanelli M (2002) Distribution of heavy metals in sediments of the Venice Lagoon: the role of the industrial area. Sci Total Environ 295(1): 35-49. https://doi.org/10.1016/S00489697(02)00040-2

Bennouna A, Assobhei O, Berland B, El Attar J (2000) Étude des populations phytoplanctoniques de la lagune de Oualidia (Maroc); dinoflagellés potentiellement nuisibles. Marine life 10(1-2): 3-18.

Blanchet H, Lavesque N, Ruellet T, Dauvin J.C, Sauriau P.G, Desroy N, Desclaux C, Leconte M, Bachelet G, Janson A.L, Bessineton C, Duhamel S, Jourde J, Mayot S, Simon S, deMontaudouin X (2008) Use of biotic indices in semi-enclosed coastal ecosystems and transitional waters habitats - Implications for the implementation of the European water framework. Ecol. Indic 8: 360-372. doi: 10.1016/j.ecolind.2007.04.003

Borja A, Dauer D.M (2008) Assessing the environmental quality status in estuarine and coastal systems: comparing methodologies and indices. Ecol Indic $8: 331-337$.

Borja A, Elliott M (2007) What does "good ecological potential" mean, within the European Water Framework Directive? Mar Pollut Bull 54(10): 1559-1564. https://doi.org/10.1016/j.marpolbul.2007.09.002

Borja A, Franco J, Perez V (2000) A marine biotic index to etablish the ecological quality of soft bottom benthos within european estuarine and coastal environnements. Mar Pollut Bull 40:1100-1114. doi: 10.1016/S0025$326 \mathrm{X}(00) 00061-8$

Carruesco C (1989) Genèse et évolution de trois lagunes du littoral atlantique depuis l'holocène : Oualidia, Moulay Bou Salham (Maroc) et Arcachon (France). Thèse de doctorat. Université de Bordeaux I, $485 \mathrm{p}$.

Chafik A, Cheggour M, Kaimoussi A (1996) Etude préliminaire de l'impact des activités de traitement et de transformation des phosphates sur le milieu marin : cas de Jorf Lasfar. Travaux et Documents de l'Institut National de Recherche Halieutique, (17), 94.

Chaouti A, Bayed A (2005) Diversité taxonomique et structure de la macrofaune benthique des substrats meubles de la lagune de Smir. Travaux de l'Institut Scientifique 4: 33-42.

Chaouti A, Bayed A (2008) Spatial patterns of soft-bottom macro-invertebrates and relationships with environmental conditions in a north African coastal lagoon (Smir lagoon, Morocco). Vie et Milieu 58(1) : 2535 .

Chbicheb A (1996). Organisation biogéologique d'un bassin paralique : la lagune d'Oualidia (côte atlantique marocaine). Thèse de Doctorat. Université de Nantes, Nantes (France), 167 p.

Cheggour M, Chafik A, Langston W. J, Burt G. R, Benbrahim S, Texier H (2001) Metals in sediments and the edible cockle Cerastoderma edule from two Moroccan Atlantic lagoons: Moulay Bou Selham and Sidi Moussa. Environ Pollut 115(2): 149-160. https://doi.org/10.1016/S0269-7491 (01)00117-8

Cherkaoui E, Bayed A, Hily C (2003) Organisation spatiale des peuplements macrozoobenthiques subtidaux d'un estuaire de la côte atlantique marocaine : l'estuaire du Bou Regreg. Cah Biol mar 22 : 339-352.

Clarke KR, Ainsworth M (1993) A method of linking multivariate community structure to environmental variables. Mar Ecol Prog Ser 92:205-219.

Damsiri Z, Natij L, Khalil K, Loudiki M, Rabouille C, Ettahiri O (2014) Spatio-temporal nutrients variability in the Oualidia lagoon ( Atlantic Moroccan coast ). Int J Curr Adv Res 2(8): 609-618. 
Dauer D.M, Ranasinghe J.A, Weisberg S.B (2000) Relationships between benthic community condition, water quality, sediment quality, nutrient loads, and land use patterns in Chesapeake Bay. Estuaries 23 (1): 80-96.

Dauvin J.C, Andrade H, De-La-Ossa-Carretero J.A, Del-Pilar-Ruso Y, Riera R (2016) Polychaete/amphipod ratios: An approach to validating simple benthic indicators. Ecol Indic 63: 89-99. Doi: 10.1016/j.ecolind.2015.11.055

Dufrêne M, Legendre P (1997) Species Assemblages and Indicator Species : The Need for a Flexible Asymmetrical Approach. Ecol Monogr 67(3), 345-366.

El Asri F, Zidane H, Errhif A, Tamsouri M. N, Maanan M, Malouli Idrissi M, Martin D (2017) Polychaete diversity and assemblage structure in the Oualidia Lagoon, Moroccan Atlantic coast. J Mar Biol Assoc UK 1-10. https://doi.org/10.1017/S0025315417000388

El Asri F, Zidane H, Maanan M, Tamsouri M. N, Errhif A (2015) Taxonomic diversity and structure of the molluscan fauna in Oualidia lagoon (Moroccan Atlantic coast ). Environ Monit Assess 187(545): 1-10. https://doi.org/10.1007/s10661-015-4752-7

El Hamoumi R, Dakki M, Rguibi Idrissi H, Radi M (2003) Fiche descriptive sur les zones humides Ramsar (FDR) : Complexe de Sidi Moussa-Walidia (Maroc).

Fauchald K, Jumars P. A (1979) The diet of worms: a study of polychaete feeding guilds. Oceanography and Marine Biology. An Annual Review 17: 193-284. https://doi.org/10.12691/marine-1-1-6

Gaudêncio M. J, Cabral H. N (2007) Trophic structure of macrobenthos in the Tagus estuary and adjacent coastal shelf. Hydrobiologia 587(1): 241-251. https://doi.org/10.1007/s10750-007-0686-6

Goss-Custard J.D, Andrew D, West A.D, Yates M.G, Caldow R.W.G, Stillman R.A, Castilla J, Castro M, Dierschke V, Le V.Dit Durell S.E.A, Eichhorn G, Ens B.J, Exo K.M, Udayangani-Fernando P.U, Ferns P.N, Hockey P.A.R, Gill J.A, Johnstone I, Kalejta- Summers B, Masero, J.A, Moreira F, Nagarajan R, Owens I.P.F, Pacheco C, Perez-Hurtado A, Rogers D, Scheiffarth G, Sitters H, Sutherland W.J, Triplet P, Worrall D.H, Zharikov Y, Zwarts L, Pettifor R.A (2006) Intake rates and the functional response in shore- birds Charadriiformes eating macroinvertebrates. Biol Rev 81: 1-29.

Grall J, Glémarec M (1997) Using biotic indices to estimate macrobenthic community perturbations in the Bay of Brest. Estuar Coast Shelf Sci 44: 43-53. https://doi.org/10.1016/S0272-7714(97)80006-6

Gray J.S, Clarke K.R, Warwick R.M, Hobbs G (1990) Detection of initial effects of pollution on marine benthos: an example from the Ekofisk and Eldfisk oilfields, North Sea. Mar Ecol Prog Ser 66: 285-299.

Guélorget O, Penhuisot J-P (1983) Le domaine paralique. Expressions géologiques, biologiques et économiques du confinement. Trav. Lab. Geol. ENS, 16, 136 p.

Guelorget O, Perthuisot J (1992) Paralic ecosystems. Vie Milieu 42(2): 215-251.

Hammer Ø, Harper D, Ryan P (2001) PAST: Paleontological statistics software package for education and data analysis. Palaeontol Electron 4:1-9.

Hassou N, Maanan M, Hennani M, Zourarah B, Assobhei O (2014) Spatial and temporal variation of faecal pollution indicators (Escherichia coli and faecal streptococci ) and physico-chemical parameters at the Oualidia lagoon and its watershed ( Morocco ). IJCMAS 3(3): 675-694.

Hennani M, Maanan M, Robin M, Cheddad K, Assobhei O (2012) Temporal and spatial distribution of faecal bacteria in the Oualidia lagoon (Morocco). Pol J Environ Stud 21(3): 627-634.

Herman PMJ, Middelburg JJ, van de Koppel J, Heip CHR (1999) Ecology of estuarine macrobenthos. Adv Ecol Res 29:195-240

Hilmi K, Koutitonsky V, Orbi A, Lakhdar J, Chagdali M (2005) Oualidia lagoon, Morocco: an estuary without a river. Afr J Aquat Sci 30(1): 1-10. https://doi.org/10.2989/16085910509503828

Hily C, Bouteille M (1999) Modifications of the specific diversity and feedingguilds in an intertidal sediment colonized by an eelgrass meadow (Zostera marina) (Brittany, France). Compt. Rend. Acad. Sci. Sect III Sci. Vie 322, 1121-1131.

Holm-Hansen O, Lorenzen C. J, Holmes R. W, Strickland J. D. H (1965) Fluorometric Determination of Chlorophyll. ICES J Mar Sci 30(1): 3-15. https://doi.org/10.1093/icesjms/30.1.3 
Idardare Z, Chiffoleau J F, Moukrim A, Alla A. A, Auger D, Lefrere L, Rozuel E (2008) Metal concentrations in sediment and Nereis diversicolor in two Moroccan lagoons: Khnifiss and Oualidia. J Chem Ecol 24(5):329340. https://doi.org/10.1080/02757540802378774

Jędruch A, Bełdowska M. Ziółkowska M (2008) The role of benthic macrofauna in the trophic transfer of mercury in a low-diversity temperate coastal ecosystem (Puck Lagoon, southern Baltic Sea). Environ Monit Assess 191, 137. https://doi.org/10.1007/s10661-019-7257-y

Jumars P. A, Dorgan K. M, Lindsay S. M (2015) Diet of Worms Emended: An Update of Polychaete Feeding Guilds. Ann Rev Mar Sci 7(1), 497-520. https://doi.org/10.1146/annurev-marine-010814-020007

Kennish M. J, Paerl H. W (2010) Coastal lagoons. Critical habitats of environmental change. In M. J. Kennish, H. W. Paerl (Eds.). Coastal lagoons. Critical habitats of environmental change (pp. 1-15). Boca Ratón, Florida: CRC Press.

Kevrekidis T (2004) Seasonal variation of the macrozoobenthic community structure at low salinities in a Mediterranean lagoon (Monolimni Lagoon, Northern Aegean). Int Rev Hydrobiol 89(4): 407-425. https://doi.org/10.1002/iroh.200310703

Kjerfve B (1994) Coastal lagoon processe (In B. Kjer). In B. Kjerfve (Ed.). Coastal lagoon processes (pp. 1-8). Amsterdam: Elsevier Science.

Lefrere L, Ouassas M, Guillois B, Gillet P, Moukrim A (2015) Macrobenthic community structure of soft-bottom sediments in the Khnifiss lagoon, South of Morocco. JMES 6(11): 3226-3235.

Maanan M (2007) Biomonitoring of heavy metals using Mytilus galloprovincialis in Safi coastal waters, Morocco. Environ Toxicol 22(5): 525-531.

Maanan M (2013) Impact des changements de l'occupation des sols sur l'état de l'environnement dans des écosystèmes côtiers : cas des lagunes d'Oualidia et de Moulay Bousselham (façade Atlantique Marocaine). Thèse de doctorat. Université Chouaib Doukkali, El Jadida (Maroc), 188 p.

Maanan M, Ruiz-Fernández A. C, Maanan M, Fattal P, Zourarah B, Sahabi M (2014). A long-term record of land use change impacts on sediments in Oualidia lagoon, Morocco. International Journal of Sediment Research, 29(1), 1-10. Doi: 10.1016/S1001-6279(14)60017-2.

Maanan M, Saddik M, Maanan M, Chaibi M (2015) Environmental and ecological risk assessment of heavy metals in sediments of Nador lagoon, Morocco. Ecol Indic 48: 616-626. https://doi.org/10.1016/j.ecolind.2014.09.034

Marchini A, Gauzer K, Occhipinti-Ambrogi A (2004). Spatial and temporal variability of hard-bottom macrofauna in a disturbed coastal lagoon (Sacca di Goro, Po River Delta, Northwestern Adriatic Sea). Mar Pollut Bull: 48(11-12): 1084-1095. https://doi.org/10.1016/j.marpolbul.2003.12.015

Marchini A, Munari C, Mistri M (2008) Functions and ecological status of eight Italian lagoons examined using biological traits analysis (BTA). Mar Pollut Bull 56(6), 1076-1085. https://doi.org/10.1016/j.marpolbul.2008.03.027

McLusky D. S, Elliott M (2004) The Estuarine Ecosystem; Ecology, Threats and Management. Third ed. OUP, Oxford, p. 216.

Mergaoui L, Fekhaoui M, Bouya D, Gheït A, Stambouli A (2003) Qualité des eaux et macrofaune benthique d'un milieu estuarien du Maroc : cas de l'estuaire de Sebou. Bulletin de l'Institut Scientifique, Section Sciences de La Vie 67-75.

Mistri M (2002) Persistence of benthic communities: A case study from the Valli di Comacchio, a Northern Adriatic lagoonal ecosystem (Italy). ICES J Mar Sci 59(2): 314-322. https://doi.org/10.1006/jmsc.2001.1169

Mistri M, Fano E. A, Rossi G, Caselli K, Rossi R (2000) Variability in macrobenthos communities in the Valli di Comacchio, northern Italy, a hypereutrophized lagoonal ecosystem. Estuar Coast. Shelf Sci 51(5): 599-611. https://doi.org/10.1006/ecss.2000.0697

Mistri M, Fano E. A, Rossi R (2001) Redundancy of macrobenthos from lagoonal habitats in the Adriatic Sea. Mar Ecol Prog Ser 215: 289-296. https://doi.org/10.3354/meps215289 
Pielou E. C (1966) Shannon's Formula as a Measure of Specific Diversity: Its Use and measure. Am Nat 100(914): $463-465$.

Platell ME, Orr PA, Potter IC (2006) Inter- and intraspecific partitioning of food resources by six large and abundant fish species in a seasonally open estuary. J Fish Biol 69:243-262

Pranovi F, Curiel D. Rismondo A, Marzocchi M, Scattolin M (2000) Determination of food sources for benthic invertebrates in a salt marsh(Aiguillon Bay, France) by carbon and nitrogen stable isotopes, importance oflocally produced sources. Sci Mar 64:303-388.

Rharbi N, Ramdani M, Berraho A, Idrissi J. L (2001) Caractéristiques hydrologiques et écologiques de la lagune d'Oualidia : milieu paralique de la côte atlantique marocaine. Marine life 11(1-2) : 3-9.

Shannon C. E (1948) A mathematical theory of communication. The Bell System Technical Journal, 27:379-423. https://doi.org/10.1145/584091.584093

Touhami F, Bazairi H, Badaoui B, Bouarour O, Benhoussa A (2017) Merja Zerga lagoon: study of the functional structure and bioassessment of the ecological quality of benthic communities. JMES 8: 4591-4599. Doi: 10.26872/jmes.2017.8.12.885

Touhami F, Bazairi H, Badaoui B, Morabbi A, Benhoussa A (2019) Structure and spatial organization of macrobenthic fauna of intertidal habitats frequented by wintering shorebirds at Merja Zerga lagoon (Moroccan Ramsar Site). Cah Biol Mar 60:41-50

Uwadiae R. E (2013) Spatial Patterns in Diversity and Distribution of Benthic Molluscs in a Weak Tidal Tropical Lagoon, Int J Mar Sci 3(14): 111-120. https://doi.org/10.5376/ijms.2013.03.0014

Velasco A. M, Pérez-Ruzafa A, Martínez-Paz J. M, Marcos C (2017) Ecosystem services and main environmental risks in a coastal lagoon (Mar Menor, Murcia, SE Spain): The public perception. J. Nat. Conserv https://doi.org/10.1016/J.JNC.2017.11.002

Ysebaert T, Herman P. M. J, Meire P, Craeymeersch J (2003) Large-scale spatial patterns in estuaries : estuarine macrobenthic communities in the Schelde estuary, NW Europe. Estuar Coast Shelf Sci 57:335-355. https://doi.org/10.1016/S0272-7714 (02)00359-1

Zourarah B (2002) Les processus côtiers actuels et leur impact sur l'environnement littoral des Doukkala: Approches hydrodynamique, morphologique, sédimentologique et géochimique. Thèse de Doctorat, Université Chouaib Doukkali, El Jadida (Maroc), 232 p.

Zourarah B, Maanan M, Carruesco C, Aajjane A, Mehdi K, Conceição Freitas M (2007) Fifty-year sedimentary record of heavy metal pollution in the lagoon of Oualidia (Moroccan Atlantic coast). Estuar Coast Shelf Sci 72: 359-369. https://doi.org/10.1016/j.ecss.2006.11.007 


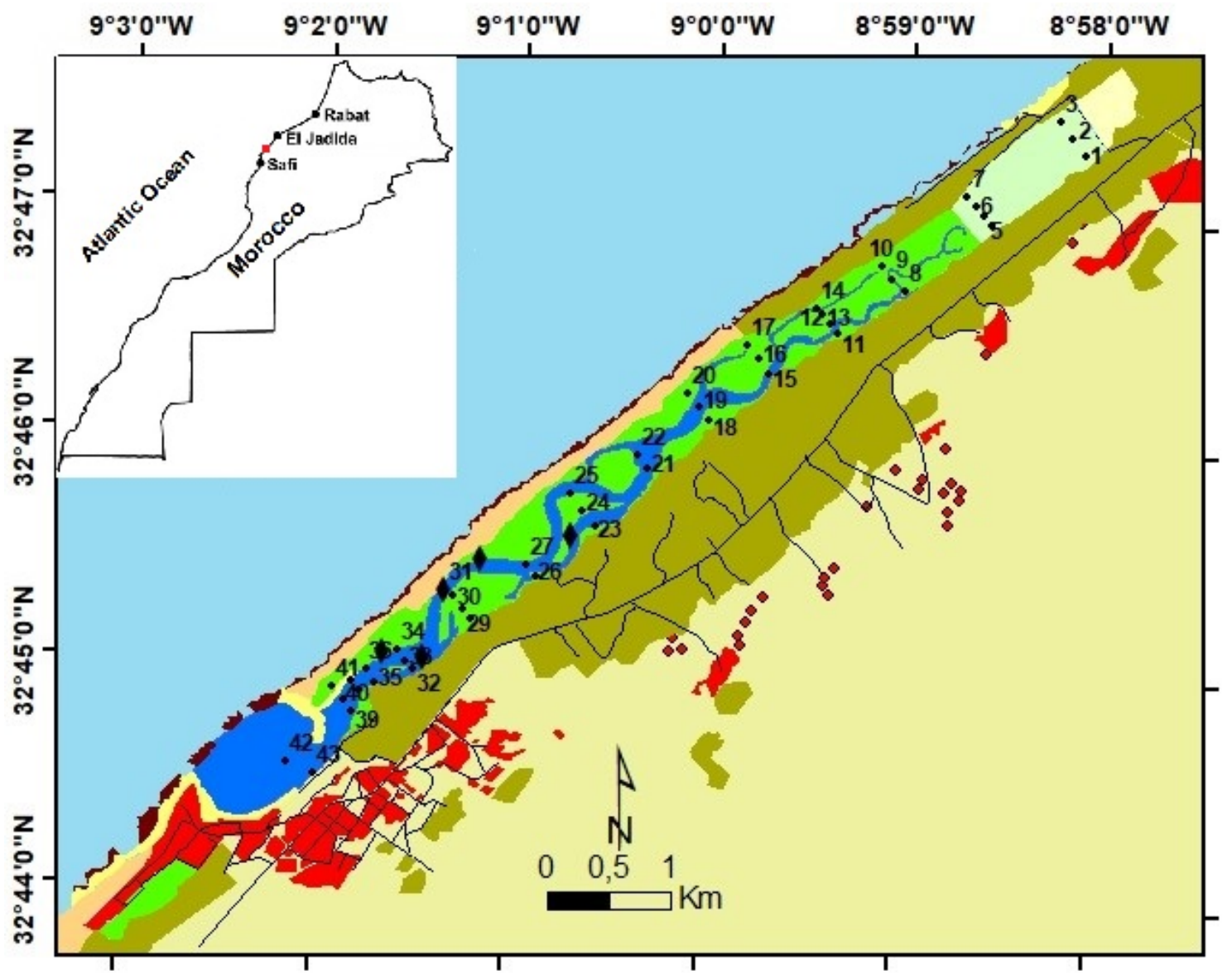

\section{Legend}

\begin{tabular}{ll|l|l|} 
- Sample & Roads & Agricultural areas & intertidal area \\
\cline { 2 - 3 } Salt marsh & Bare rocks & Construction areas & Pasture/ Crop \\
Sullies & Dunes & Lagoon & Oyster farms
\end{tabular}

Figure 1. Geographical location of the Oualidia lagoon, showing the position of the sampling stations. 
Table 1. Comparative list the macrofauna collected in 2013 (our study) and 1996 (Chbicheb 1996) in Oualidia.

\begin{tabular}{|c|c|c|c|}
\hline Family & Species & $\begin{array}{l}\text { This } \\
\text { study }\end{array}$ & $\begin{array}{c}\text { Chbicheb } \\
\text { (1996) }\end{array}$ \\
\hline \multicolumn{4}{|l|}{ Mollusca } \\
\hline Solenidae & Solen marginatus Pulteney, 1799 & $*$ & \\
\hline \multirow{2}{*}{ Cardiidae } & Cerastoderma edule (Linnaeus, 1758) & $*$ & $*$ \\
\hline & Cerastoderma glaucum (Poiret, 1789) & & $*$ \\
\hline \multirow{2}{*}{ Semelidae } & Abra alba (W. Wood, 1802) & $*$ & \\
\hline & Scrobicularia plana (da Costa, 1778) & $*$ & $*$ \\
\hline Lucinidae & Loripes orbiculatus Poli, 1791 & $*$ & $*$ \\
\hline Mactridae & Spisula subtruncata Da Costa, 1778 & $*$ & \\
\hline \multirow{2}{*}{ Veneridae } & Ruditapes decussatus (Linnaeus, 1758) & $*$ & $*$ \\
\hline & Venerupis Pullastra (Linné, 1758) & & $*$ \\
\hline Mytilidae & Mytilus galloprovincialis Lamarck, 1819 & $*$ & \\
\hline Haminoeidae & Haminoea cf. japonica Pilsbry, 1895 & * & \\
\hline Aplysiidae & Aplysia punctata (Cuvier, 1803) & $*$ & \\
\hline Runcinidae & Runcina coronata (Quatrefages, 1844) & $*$ & \\
\hline Onchidiidae & Onchidella celtica (Cuvier, 1817) & $*$ & \\
\hline Ellobiidae & Myosotella myosotis (Draparnaud, 1801) & $*$ & \\
\hline Discodorididae & Jorunna tomentosa (Cuvier, 1804) & * & \\
\hline Dendrodorididae & Dendrodoris sp. & $*$ & \\
\hline Epitoniidae & Epitonium clathrus (Linnaeus, 1758) & * & \\
\hline Hydrobiidae & Peringia ulvae (Pennant, 1777) & $*$ & \\
\hline \multirow[t]{2}{*}{ Muricidae } & Hexaplex trunculus (Linnaeus, 1758) & $*$ & \\
\hline & Tritia pfeifferi (Philippi, 1844) & $*$ & \\
\hline \multirow[t]{3}{*}{ Nassariidae } & Tritia reticulata (Linnaeus, 1758) & $*$ & $*$ \\
\hline & Tritia mutabilis (Linnaeus, 1758) & & $*$ \\
\hline & Phorcus sauciatus (Koch, 1845) & $*$ & \\
\hline \multirow{3}{*}{ Trochidae } & Phorcus lineatus (da Costa, 1778) & $*$ & * \\
\hline & Gibbula umbilicalis (da Costa, 1778) & * & * \\
\hline & Gibbula divaricata (Linnaeus, 1758) & & $*$ \\
\hline \multirow[t]{2}{*}{ Phasianellidae } & Tricolia $\mathrm{sp}$ & $*$ & \\
\hline & Patella rustica Linnaeus, 1758 & $*$ & \\
\hline \multirow[t]{2}{*}{ Patellidae } & Cymbula safiana (Lamarck, 1819) & $*$ & \\
\hline & Patella depressa Pennant, 1777 & $*$ & \\
\hline Cerithiidae & Cerithium vulgatum (Bruguière, 1792) & & * \\
\hline Lepidochitonidae & Lepidochitona cinerea (Linnaeus, 1767) & * & \\
\hline Octopodidae & Octopus vulgaris Cuvier, 1797 & $*$ & \\
\hline \multicolumn{4}{|l|}{ Polychaeta } \\
\hline Nereididae & Hediste diversicolor (O.F. Müller, 1776) & $*$ & $*$ \\
\hline Phyllodocidae & Phyllodoce sp. & $*$ & \\
\hline Glyceridae & Glycera alba (O.F. Müller, 1776) & $*$ & \\
\hline \multirow{2}{*}{ Nepthyidae } & Nephtys hombergii Savigny in Lamarck, 1818 & $*$ & $*$ \\
\hline & Nephtys caeca (Fabricius, 1780) & & $*$ \\
\hline Onuphidae & Diopatra cf. marocensis Paxton et al, 1995 & * & \\
\hline Ampharetidae & Alkmaria romijni Horst, 1919 & $*$ & \\
\hline Oweniidae & Owenia fusiformis Delle Chiaje, 1844 & & $*$ \\
\hline \multirow{2}{*}{ Capitellidae } & Capitella sp. & * & \\
\hline & Capitella capitata (Fabricius, 1780) & & $*$ \\
\hline \multicolumn{4}{|l|}{ Crustacea } \\
\hline \multirow{2}{*}{$\frac{\text { Gammaridea }}{\text { Melitidae }}$} & & * & \\
\hline & Melita palmata (Montagu, 1804) & $*$ & \\
\hline \multirow{2}{*}{ Corophiidae } & Corophium sp. & $*$ & \\
\hline & Corophium volutator (Pallas, 1766) & & $*$ \\
\hline Cirolanidae & Eurydice pulchra Leach, 1815 & $*$ & \\
\hline Anthuridae & Cyathura carinata (Krøyer, 1847) & $*$ & \\
\hline Sphaeromatidae & Sphaeroma serratum (Fabricius, 1787) & $*$ & \\
\hline Idoteidae & Idotea balthica (Pallas, 1772) & $*$ & \\
\hline
\end{tabular}




\begin{tabular}{|c|c|c|c|}
\hline Tanaididae & Tanais dulongii (Audouin, 1826) & $*$ & \\
\hline Apseudidae & Apseudes sp. & $*$ & \\
\hline Cumacea & spp. & $*$ & \\
\hline Copepoda & spp. & $*$ & \\
\hline Ostracoda & spp. & $*$ & \\
\hline Paguridae & $\begin{array}{l}\text { Pagurus bernhardus (Linnaeus, 1758) } \\
\text { Portunus elegans Portunus sp. }\end{array}$ & $*$ & $*$ \\
\hline Portunidae & Carcinus maenas (Linnaeus, 1758) & $*$ & $*$ \\
\hline Palaemonidae & Palaemon elegans Rathke, 1837 & $*$ & $*$ \\
\hline Balanidae & Balanus sp. & $*$ & \\
\hline \multicolumn{4}{|l|}{ Insecta } \\
\hline Chironomidae & & $*$ & \\
\hline \multicolumn{4}{|l|}{ Ehinodermata } \\
\hline Holothuriidae & Holothuria poli Delle Chiaje, 1824 & $*$ & $*$ \\
\hline Ophiuridae & Ophiura sp. & $*$ & \\
\hline \multicolumn{4}{|l|}{ Cnidaria } \\
\hline Hormathiidae & Calliactis parasitica (Couch, 1842) & $*$ & $*$ \\
\hline
\end{tabular}
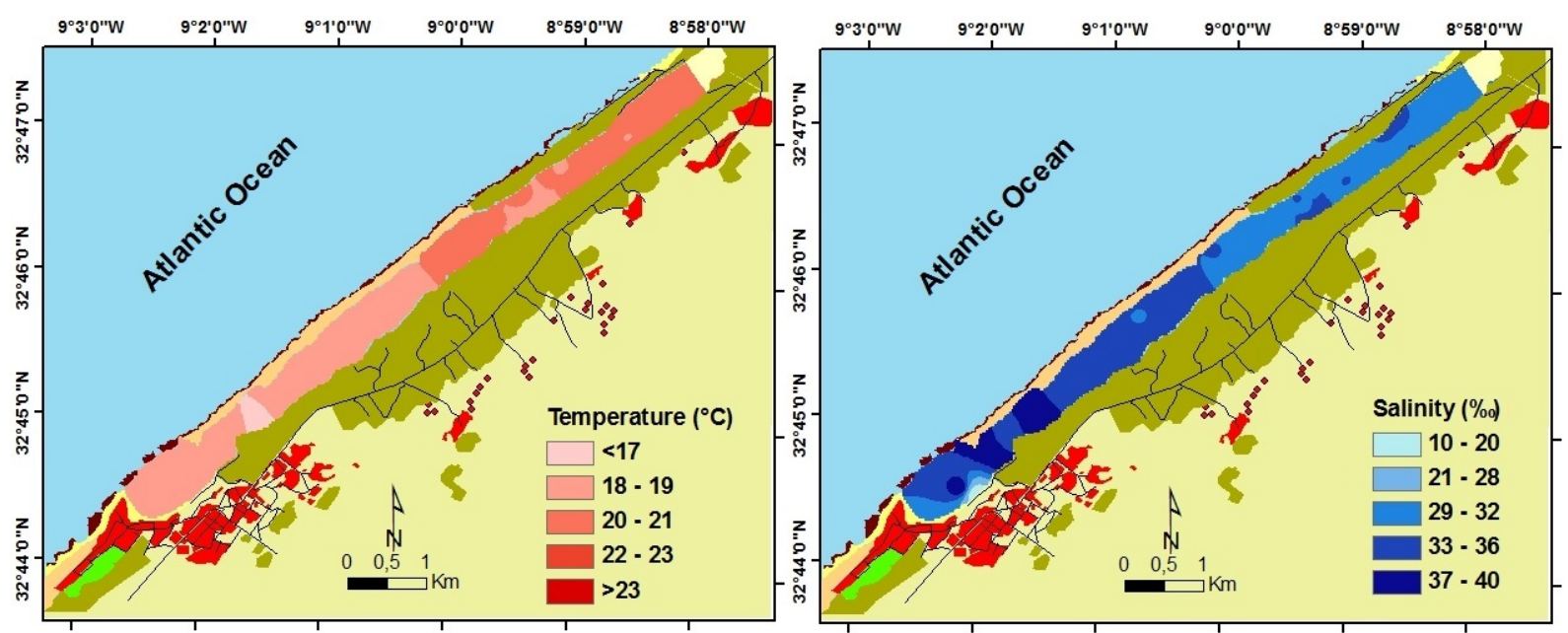

Figure 2. Distribution of temperature and salinity in the Oualidia lagoon.
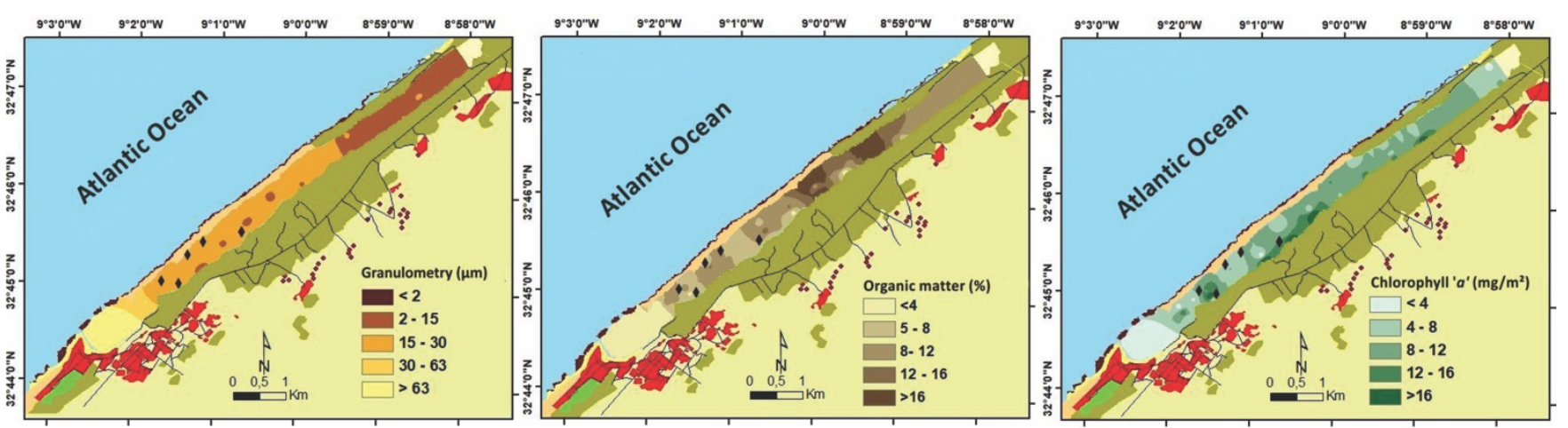

Figure 3. Distribution of organic matter, chlorophyll $a$ and granulometry in Oualidia. 

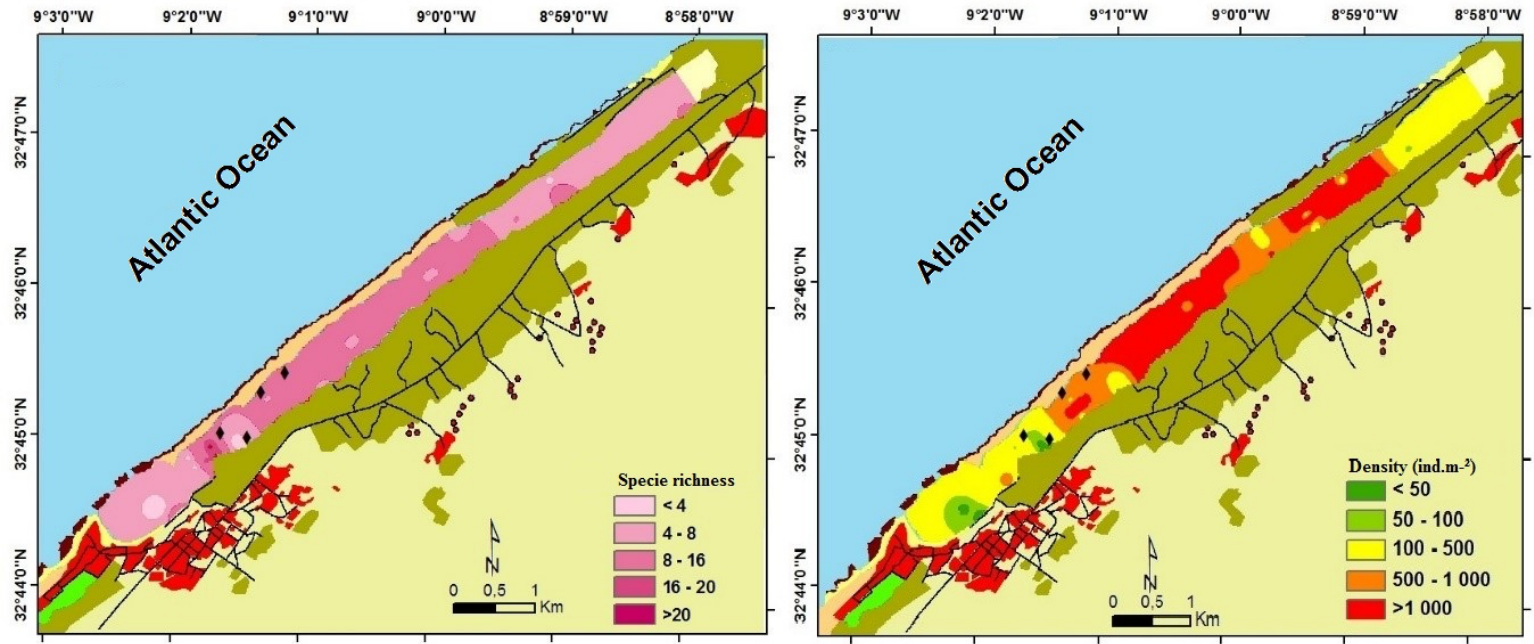

Figure 4. Spatial distribution of density and species richness in Oualidia.
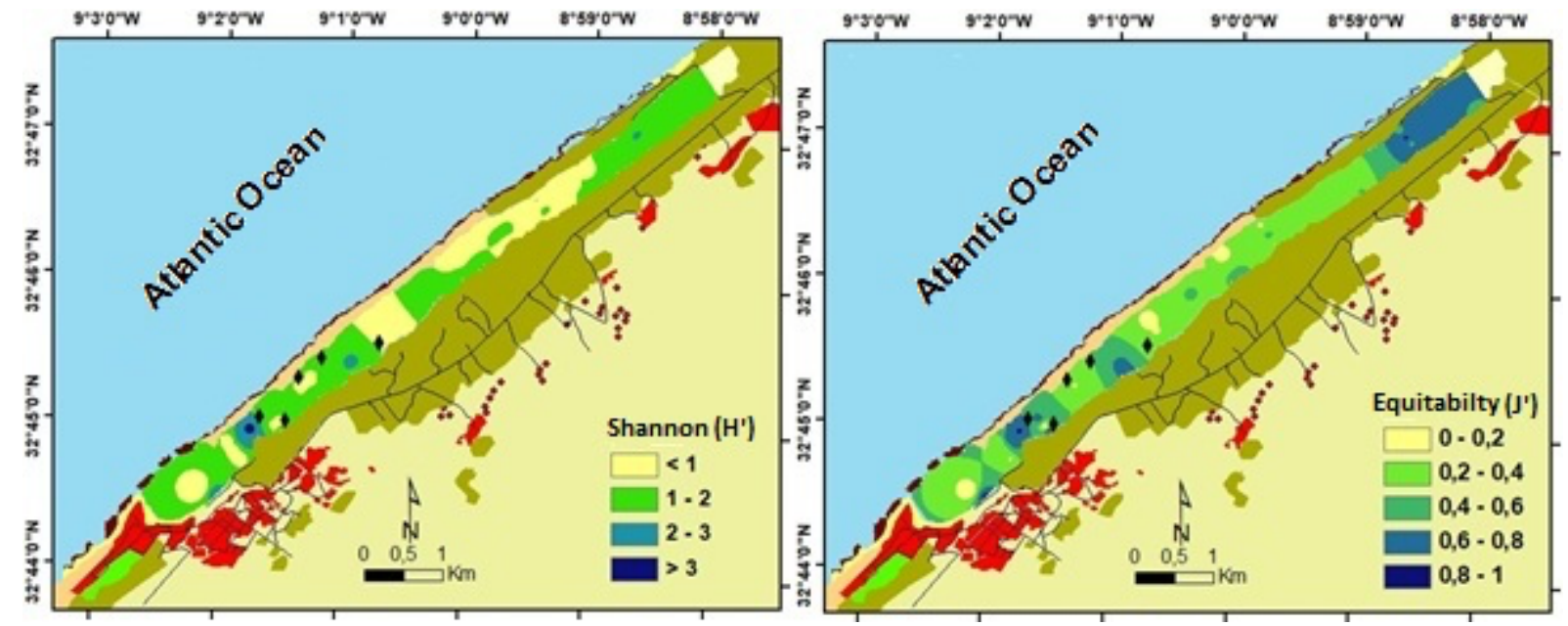

Figure 5. Spatial distribution of Shannon and evenness indexes in the Oualidia lagoon.

A

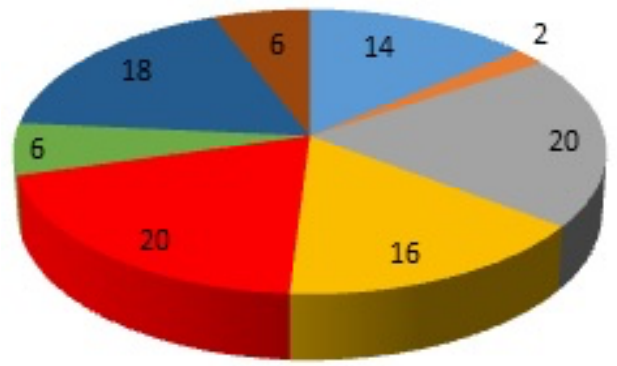

B

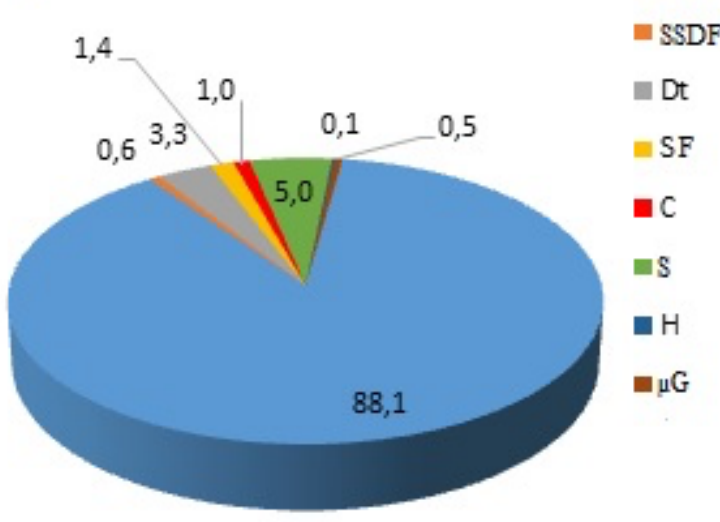

Figure 6. Trophic structure of the macrofauna community in Oualidia, expressed as relative number of individuals (A) and species (B). 


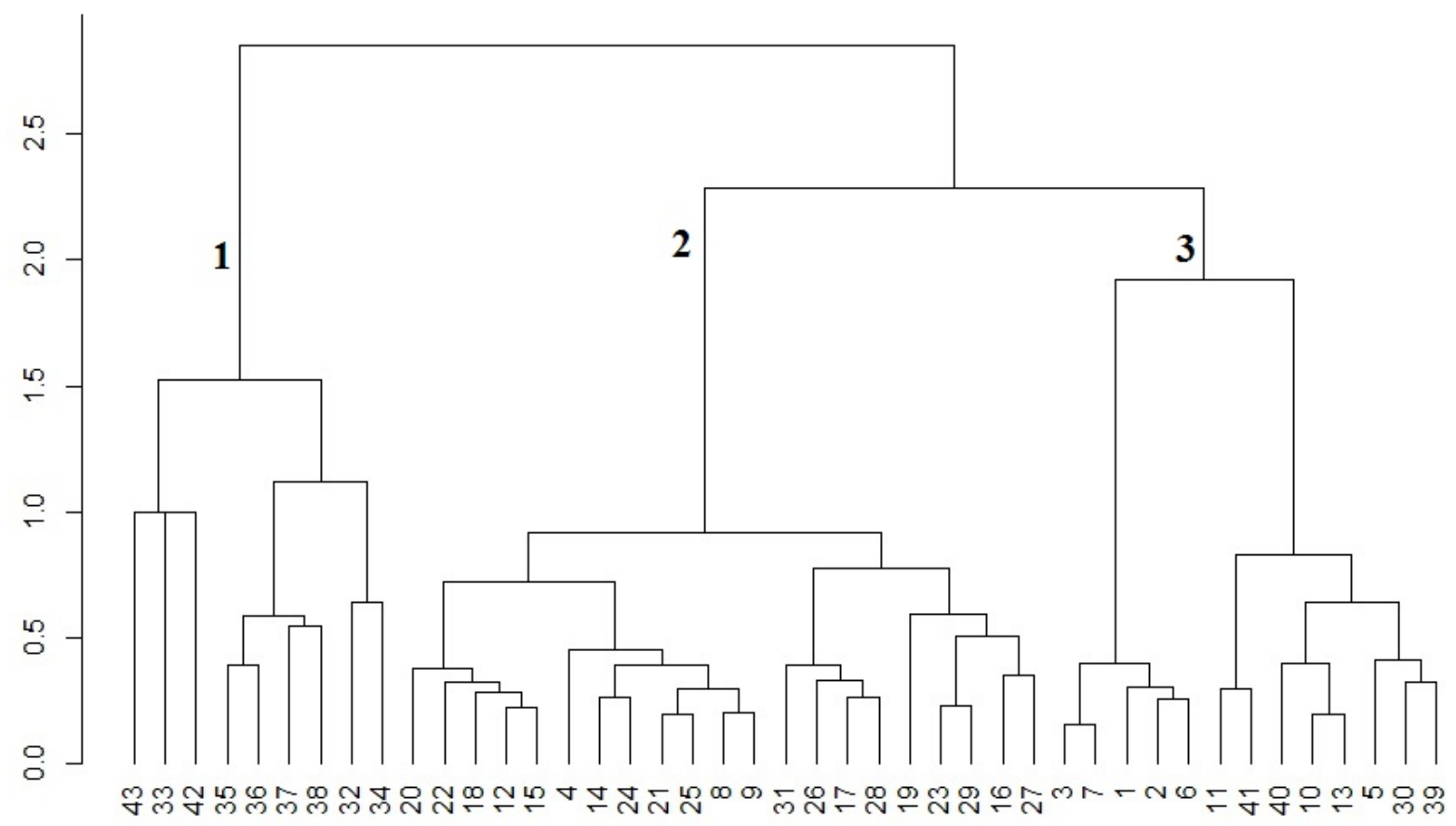

Nonmetric MDS

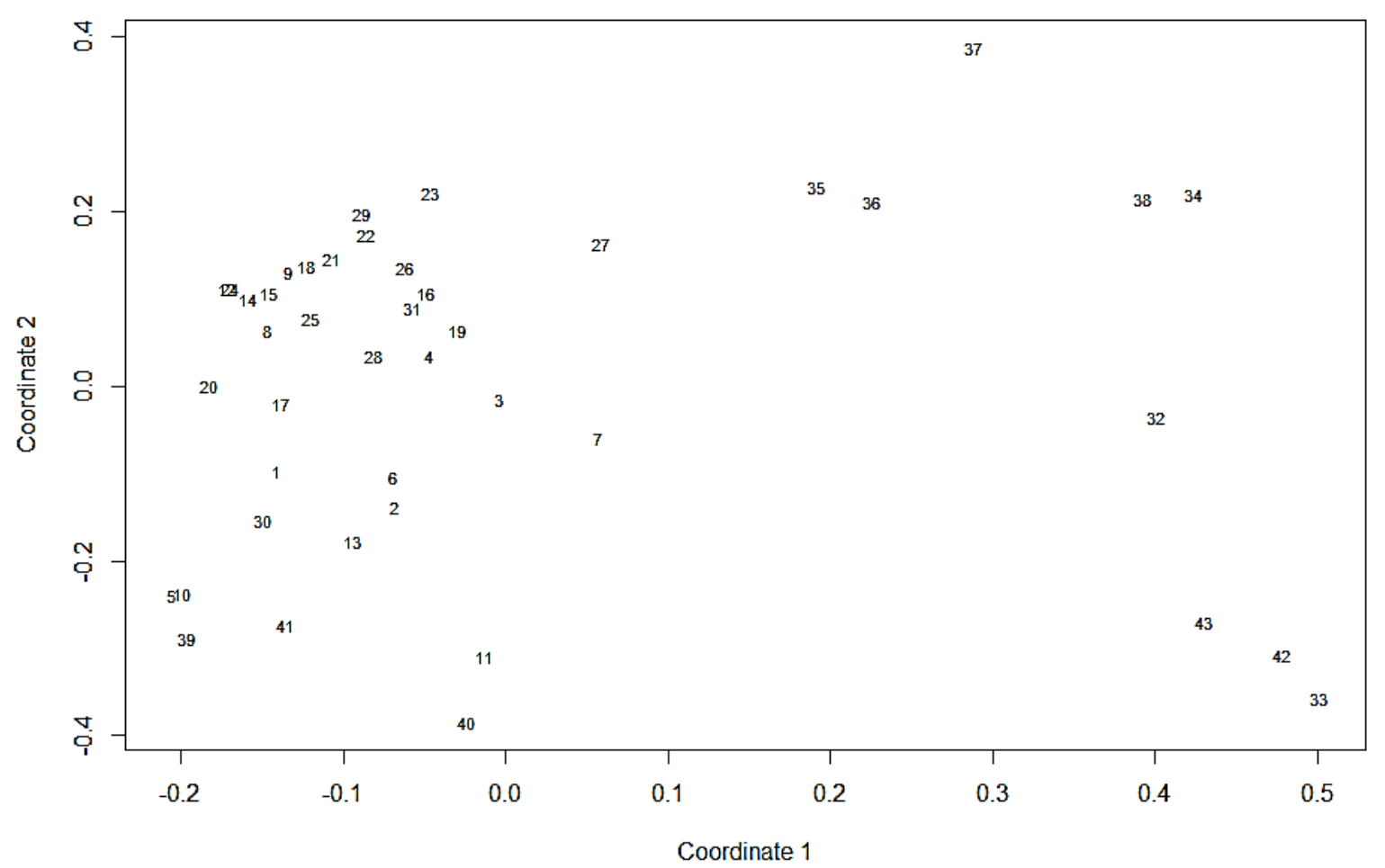

Figure 7. Structure of the macrofaunal assemblages based on abundances. A. Dendogram inferred from HAC. B. MDS plot showing the groups inferred from HAC. 


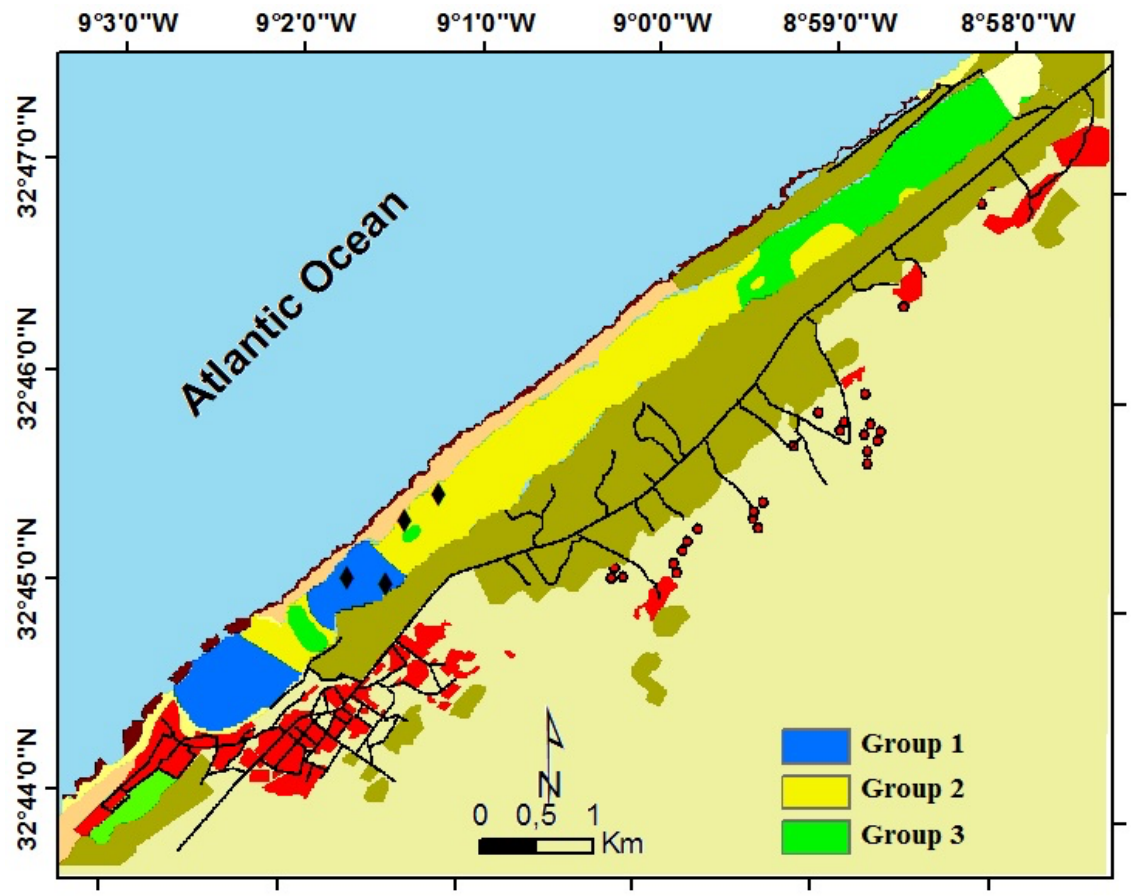

Figure 8. Spatial distribution of the groups obtained in the HAC and nMDS analyses in Oualidia.

Table 2. List of the main species of the macrofaunal assemblages inferred from the HAC and nMDS analyses according to the IndVal index. The species showing the highest IndVal are highlighted in bold.

\begin{tabular}{clc}
\hline Groups & Species & IndVal \\
\hline \multirow{4}{*}{$\mathbf{1}$} & Tanais dulongii & 322.8 \\
& Tritia reticulata & 262.5 \\
& Runcina coronata & 196.9 \\
& Idotea balthica & 187.5 \\
& Ruditapes decussatus & 182.8 \\
\hline \multirow{2}{*}{$\mathbf{2}$} & Tritia pfeifferi & 191.7 \\
& Abra alba & 185.4 \\
& Peringia ulvae & 184.4 \\
& Hediste diversicolor & 116.9 \\
& Calliactis parasitica & 111.6 \\
\hline \multirow{3}{*}{} & Cerastoderma edule & 102.3 \\
& Haminoea cf. japonica & 92 \\
& Chironomus sp. & 45.6 \\
& Hediste diversicolor & 44.7 \\
& Capitella sp. & 26.3 \\
\hline
\end{tabular}

Table 3. Summary of BIOENV results.

\begin{tabular}{lcc}
\hline Variables & size & correlation \\
\hline Salinity & 1 & 0.4612 \\
Salinity \& granulometry & 2 & 0.5404 \\
Temperature, salinity \& granulometry & 3 & 0.5414 \\
Temperature, salinity, chlorophyll “a” \&granulometry & 4 & 0.4668 \\
Temperature, salinity, chlorophyll "a”, organic matter \&granulometry & 5 & 0.4002 \\
\hline
\end{tabular}

